\title{
Diet and cuisine: farming and its transformations as reflected in pottery
}

\author{
Andrew Sherratt \\ Ashmolean Museum and Institute of Archaeology, University of Oxford, UK \\ andrew.sherratt@ashmus.ox.ac.uk
}

\begin{abstract}
In the absence of direct evidence from organic residues, the character of pottery assemblages provides valuable indications of changes in diet and cuisine. This paper considers the possibility of major innovations in food-processing in the millennia following the introduction of farming, and relates these to contemporary processes of urbanisation in the Near East.
\end{abstract}

IZVLEČEK - Keramika nam daje dragocene podatke o spreminjanju prehrane in kuhanja, saj neposrednih organskih ostankov nimamo. V̌clanku se ukvarjamo z možnostjo, da je v tisočletjih po uvedbi kmetovanja prišlo do velikih sprememb v pripravljanju hrane. Te spremembe primerjamo s sodobnimi procesi urbanizacije na Bližnjem vzhodu.

KEY WORDS - diet, prehistoric; cuisine, prehistoric; pottery, prehistoric; fermentation

\section{INTRODUCTION}

The thesis of this paper is that the continent of Europe - and indeed much of the Old World - underwent three profound changes in diet during the Holocene period. The first of these was the beginning of farming, and the most recent was the Industrial Revolution; but it is the one in between these two, which concerns me here. This episode is what I once labelled the "secondary products revolution" (Sherratt 1981), and the rather cumbersome term which I chose for it was necessary because it had no counterpart in the terminology we have inherited from the "speculative historians" of the Enlightenment the classic division into hunters, farmers and towndwellers by which we traditionally classify the major contrasts in ways of life. ${ }^{1}$ Since Gordon Childe invented the phrase "Neolithic Revolution", John Lubbock's archaeological term "Neolithic" has been equa- ted with the beginning of farming; and in much of Europe (though not in China, Siberia, or Boreal Europe) the introduction of polished axes for forestclearance - and pottery as food containers - is a reliable indicator of the major shift in food-sources and diet which accompanied the introduction of cereals. Thereafter, however, the equation between traditional terminologies and major dietary changes becomes unclear. Although some new species of crop-plants (notably tree-crops) and livestock (though mainly species important for transport) were added, the staple domesticates established in the Neolithic continued to provide the basic sources of food (though supplemented, first in the Roman period by the introduction of Oriental domesticates, and after the discovery of the Americas by New World ones). To a large extent, this was also true of the Industrial

1 Although in fact, as I shall argue below, the "Urban Revolution" was responsible for many of the changes which can be perceived in contemporary Europe - so the Enlightenment theorists were not entirely wrong in selecting their break-points. Where their model is inappropriate is in constructing unilinear, stadial models of change, whereas what is required here is a historical account of the historical effects of the co-existence of urban and non-urban societies (of the kind provided by world system theories). The Romantic critique of Enlightenment system-building is a necessary corrective to ahistorical models of the past (and world system theory is thus a Romantic rather than an Enlightenment construction). 
Revolution: the dietary changes which took place then were more the result of new forms of food processing than of the use of newly domesticated species of plants or animals. It is this insight which I would like to deploy in trying to understand postNeolithic dietary changes in Europe and the Near East, in concentrating on forms of food processing as important elements of dietary change in early times.

The point at issue may be formulated as follows. Farming introduced new sources of nourishment, such as cultivated cereals instead of collected seeds and nuts, and domesticated species of livestock instead of hunted mammals; but the types of food which were produced from them may not have been completely different from those consumed in Mesolithic times. Cereals undoubtedly made a major difference to diet in terms of their calorific contribution, and the evidence of rates of dental caries shows how this increased carbohydrate component affected oral health (as well as being important for demographic characteristics such as birth rates); similarly, the introduction of domestic animals was often accompanied a significant decline in the contribution made by fishing or the hunting of marine mammals. At the same time, the proliferation of pottery types (often carefully decorated) shows that food was being served in more elaborate ways than the "one-pot meals" of pottery-using Mesolithic groups such as Ertebølle. All of this points to a significant degree of alteration both in diet and cuisine associated with the beginning of farming. Nevertheless it would be misleading to imagine that this involved an instantaneous transition to the kinds of foods consumed by European peasants in medieval times, with their reliance on bread, beer and cheese. I would like to raise the possibility that the potential range of foods which could be produced from the plants and animals introduced in the Neolithic was only slowly explored, and that important forms of food processing made their appearance in Europe some millennia after the transition to farming. In particular, I would like to suggest that certain modes of food preparation involving fermentation are likely to have been pioneered outside Europe (or at least outside northern and central Europe), in areas where abundant sunshine was associated with sugar-rich fruits, or where complex societies allowed a greater degree of specialisation in production and processing. 2

This formulation is, I hope, simply a matter of reasonable expectation. My further suggestion, however, relates to the timing of such changes and the pattern of their spread. It is here that the study of pottery becomes important as an indicator of how and when such innovations may have taken place. Although Europe lacks the pictorial record which is so informative in Egypt and Mesopotamia, the detailed typologies of pottery vessels created by European archaeologists (although compiled largely for chronological purposes and cultural taxonomy) can provide sensitive indicators of changing practices in the manipulation of stored staples, culinary processing, and the presentation of comestibles. Ceramic specialists have identified major alterations in the nature of pottery assemblages during the later fourth and third millennia BC. In south-east Europe, this is the fourth-millennium horizon which marks the end of "Eneolithic" assemblages and the beginning of "Early Bronze Age" ones (in quotation marks because this change does not coincide with the introduction of bronze, and because the widespread and easily recognisable changes in ceramic forms are a more useful marker of cultural changes than the rarer metal types). In central Europe this horizon is closely paralleled by the beginning of Baden, which has some echoes in the pottery forms of assemblages in the North European Plain; but in the latter area the more radical change occurs with the spread of Corded Ware in the third millennium, and in Atlantic Europe with Bell-Beakers. These continent-wide alterations are symptomatic of profound changes taking place over vast areas of Europe. They are undoubtedly associated with changes in the social significance of items of material culture (and not least in the beginning of a shift from pottery to metalwork as the carrier of messages about social status); but they are also, and most fundamentally, changes in the character of containers used for food and drink.

In asserting the importance of these changes as potential indicators of alterations in diet, I do not wish to erect an artificial contrast between subsistence and semiotics: changes in the types of food consumed are themselves closely related to social signalling, and the appearance of distinctive pottery types such as Beakers - which are prominently displayed in funerary depositions, and seem to have been closely associated with particular social roles are themselves likely to be indications of socially differentiated patterns of consumption. Indeed, the use of comestibles requiring a concentration of particular ingredients (such as the sources of sugar required for fermentation, for instance) implies a de-

2 These two points are not independent, in that the growth of social complexity was in itself partly an outcome of this ecology. 
gree of real power in commanding the mobilisation of relatively scarce resources. It is typical of the introduction of new dietary elements that they should first appear as the prerogative of a minority, before becoming more generally available to the population as a whole. Similar observations could be made about many material possessions - in this context about woollen clothing, metal axes, wheeled vehicles, or horses, for instance. In the long run, all of these items became relatively common items, at least in elite households. Their initial appearance as social markers does not preclude their contribution to a more general long-term transformation of patterns of possession and consumption. What it does represent, however, is an exploration of the "opportunity space" opened up by the initial innovations of domestication (and the arts of pottery-making, carpentry, and metallurgy which followed). In this sense, it was a predictable second round of innovations following on from the major transformation of the Neolithic itself. In terms of food and cuisine, it was expressed in more specialised forms of cultivation and herding, the concentration of particular resources, and longer chains of preparation (all of which increased the value and decreased the general availability of the final product): characteristics which depend as much on social arrangements as on the simple fact of the domestication of the species concerned (Sherratt 1999).

The dating of this round of innovations is significant for where it was initiated and how it took place. We have noted that the transformation moved from south to north (and more specifically south-east to north-west), and that it took place in the later fourth and third millennia $\mathrm{BC}$ - precisely the time at which the earliest urbanisation was occurring in the Near East. This at once suggests that the "Urban Revolution" may have been an important element in this transformation of Old World diets, since the larger scale of production and specialisation which accompanied it is likely to have resulted in new forms of specialised food preparation, just as it was marked by new forms of capital-intensive pottery production (using the potter's wheel), and the employment of animal traction. The socially differentiated and hierarchical character of the world's first urban commu- nities would have provided the setting for experimentation in food-processing techniques, which later became more widespread and ultimately came to represent normal practice over a large part of the old World.

This is the scenario, which I shall attempt to defend in the remainder of this paper - first by a brief discussion of models of change, then by some historical and ethnographic comparisons, and then by returning to the archaeological record.

\section{MODELS OF CHANGE}

The eight thousand years which separate the introduction of farming to Europe from the more familiar dietary patterns of the medieval period must undoubtedly have seen major changes in European eating habits, and it is worth asking how we might approach a problem of this magnitude. Just as the accounts of prehistoric Europe written by Gordon Childe and his contemporaries were constrained by the short chronologies then prevailing, and gave interpretations in terms of events such as megalithic missionaries, the intervention of Mycenaean merchants and prospectors, or military invasions (which all now seem anachronistically out of place in early prehistory, and were based on Childe's knowledge of the first-millennium world of Phoenicians, Greeks and Romans), so our models of food and dietary change need to be accommodated to the new perspective of deep time, and not just assume unchanging "traditional" practices persisting for what we now know are many millennia of prehistoric existence. 3 We need to recognise how very different such earlier practices may have been from the kind of homogenised theme-park reconstructions of life in the past, based on a mixture of historical illustrations and a liberal dash of romantic imagination, which are all too common in popular accounts of prehistoric life. Writing prehistory is a constant struggle to recognise this essential otherness of the distant past, and to guard against using anachronistic images of it. As a mental exercise, if nothing else, it is useful to try consciously to imagine how unfamiliar life in the Neolithic may have been, and to en-

\footnotetext{
3 A similar point may be made in connection with Egypt and Mesopotamia, where an abundant textual and representational record for the last five millennia tempts us to reconstruct "traditional" Egyptian or Mesopotamian practices, and to extrapolate them to time immemorial, ie prehistory. But these well-known practices are the traditions of already urbanised societies; and even ethnographic descriptions of, for example, rural Sudanese societies concern areas to which urban-generated practices had ample opportunity to spread, so they cannot be accounted representative of the indigenous practices of the early fourth millennium BC. Historical and ethnographic evidence may well be very helpful for later periods: but there is a danger that for earlier, prehistoric times it may be fundamentally misleading.
} 
visage a world where many now common elements of it did not exist; and nowhere is this conscious effort of imagination more necessary than in talking about food and the practices of food preparation.

There is a danger here, of course, in opposing "the familiar" and "the other" in direct confrontation, so that we artificially create a revolutionary transition between what we know and what we can only imagine. (This has happened to some extent, in my opinion, in models of an "Upper Palaeolithic Revolution" giving rise to the "modern mind".) It is as well to be aware of this danger, but it is equally well to be aware that change may, indeed, take precisely this form. In the case of the Middle to Upper Palaeolithic transition in Europe, for instance, the replacement of the Neanderthals on the northern margins of the hominid distribution was just such a "revolutionary" event (in terms of Pleistocene chronologies), even though the emergence of modern humans in Africa or southern Asia is likely to have been a continuing and extended evolutionary process. The expansion of modern humans into Europe had an "event-like" character precisely because of this long earlier build up of innovations. This Pleistocene analogy may seem to be remote from our present concern with Holocene changes in food-practices, but in fact it is a useful reminder both of relative rates of change and of the scale on which explanations of such major transformations need to be constructed. In terms of relative timescales, it may be noted that both the Middle to Upper Palaeolithic transition and the development of farming systems based on secondary products were processes that were paced by a mixture of biological and cultural changes - in the former case by the bio-cultural coevolution of the human species itself, in the latter case by the development of new breeds of livestock or the domestication of new types of crop (or the discovery of new forms of processing which resulted from mixing their products). A Pleistocene perspective on rates of change in the earlier Holocene may be more appropriate for our purposes than the faster pace of change in historical societies of the later Holocene, nearer to the present day. ${ }^{4}$ In the second place, understanding the Middle to Upper Palaeolithic transition requires putting European developments in a wider geographical context, including the adjacent parts of Asia and Africa where modern humans evolved. The same is true of the introduction of farming, in which developments in Europe can only be understood in relation to contemporary changes in the Near East; and I would argue that the same is true of the second round of dietary changes which are under consideration here.

\section{FEEDING THE IMAGINATION}

Bearing in mind the dangers inherent in using these methodologies (which are the only ones we have), we may continue to explore the implications of this line of thought. The ethnohistorical archive ("rural life"/folklore/European ethnography) and direct historical evidence (textual descriptions or visual illustrations) are an invaluable aid in giving life to the dry residues of the archaeological record. But we should ask ourselves how far back in time they continue to be useful. As a first approximation, we can use them as default assumptions in reconstructing the ways of life of "barbarian Europe" in the first millennium BC (using the term "barbarian" to designate the neighbouring, non-literate societies described by classical authors). In this sense Herodotus may be - in the phrase used by Kenneth Jackson to describe Old Irish epic literature - "a window on the Iron Age". Beyond the Iron Age, however, the familiar images of rural villages can potentially be quite misleading. While both the mud brick shrines of Neolithic Çatalhöyük (with their built-in vulture beaks) and the megalithic collective tombs of western Europe seem appropriately alien, the long-house villages of the LBK loesslands look reassuringly familiar in a way which may be deceptive (as can be seen from reconstructions which make LBK settlements look like medieval villages, with neatly ploughed fields). The Copper Age cemeteries of southeast Europe also have a deceptively familiar appearance; although the Varna "cemetery", whose many "burials" without bodies hint at ritual practices beyond the sorts of cultural norms implied by these terms, offers a warning against interpreting these interments as if they were examples of modern burial practices. Even where the evidence seems at first sight to be interpretable within the expectations gained from experience of more recent societies, we

\footnotetext{
4 Indeed, the late Pleistocene encounter of Neanderthals, biologically adapted to cold by their physique, with modern humans, culturally adapted by their ability to make skin clothing, offers a rather interesting analogy for the interaction in the fourth millennium BC between simple farmers developing on a "prehistoric" timescale, and dense urban communities whose society was already subject to "historical" rates of change. In both cases, two modes of evolution, broadly successive in time, temporarily confronted each other in a historical encounter.
} 
should be aware that ancient lifeways might have been quite radically different from our own culturally situated expectations. 5

If analogies from historical Europe cannot be projected back into the deep past, where else can we turn for guidance? The obvious answer is to world ethnography, which can suggest a wider range of possibilities than the limited body of later European experience. This is indeed a suggestive and informative body of observations; but we should again be aware of difficulties and biases. The most obvious is that societies recorded ethnographically exist for the most part (and with good reason) in very different environments from those of the inhabitants of prehistoric Europe - for instance in the tropics, or at any rate using different forms of crops and livestock from those we are considering. Also, they are not "prehistoric" in the same sense as the early inhabitants of Europe, having existed for many millennia alongside "historical" communities and in many cases been profoundly influenced by them. Nevertheless they can usefully provide analogies and models for certain aspects of European societies in prehistoric times, and alternative labels and descriptions for the earlier phases. The idea that early farming may have been quite small in scale, and involved gardening (horticulture) rather than large-field cultivation (agriculture), is a helpful one in imagining the nature of the earlier Neolithic, for instance. In fact the older literature on comparative ethnology (Völkerkunde) contains abundant information on matters such as dietary practices, often within an "evolutionary" framework and directed towards illuminating questions of long-term change, even when their evidence is primarily ethnographic. A good example is Adam Maurizio's Die Geschichte unserer Pflanzennahrung von den Urzeiten bis zur Gegenwart (such works are seldom less than encyclopedic!) of 1927, or his Geschichte der gegorenen Getränke of 1933, which contain both a mass of observations and a perceptive reconstruction of matters not often explicitly considered by archaeologists, but nevertheless quite fundamental to understanding prehistoric societies. ${ }^{6}$ It is from these kinds of discussion that I have drawn in elaborating my scenario for the transformation of Neolithic Europe.

Consider the following description, from Gudmund Hatt's Farming of non-European Peoples (1961. 230), 7 reconstructing the development of culinary practices following the domestication of cereals. After adding water to the crushed grain, he argues, ... one line of development leads via gruel and porridge to bread; another line, making use of fermentation, leads to beer, wine and to stronger alcoholic beverages [and thus also to leavened bread]. Alcoholic drinks were not originally known to all agriculturalists; they were unknown in North America north of Mexico, and to many of the semi-agriculturalists [i.e. horticulturalists] of South America. Bread is of more recent origin than porridge, but is probably older than beer and therefore more widely spread. The earliest kinds of bread are unleavened. The Indians of central and North America had two types of bread: boiled corn [maize] bread and baked corn bread. The latter kind, called tortilla in Spanish America is a flat cake or bannock 8 baked in the ashes or on a griddle. Similar flat cakes are known from many parts of the world, including Europe [and the Near East]. The baking of leavened bread started very early in Babylonia and Egypt, and seems to have to do with the brewing of beer; for grain was malted not only for beer but also for bread. Old fashioned unleavened bannocks continued to be made by European peasants until lately... The use of beer yeast in bread seems to have started in [rural] France as late as the seventeenth century.

Here is a reconstruction, based on the relative extent of spatial distributions in the ethnographic record (and principally in the New World, which was closer in time to the origins of farming there) which suggests a temporal succession, from early simple uses of cereals to more advanced forms of processing and transformation involving fungal micro-domesticates, the yeasts, and methods of converting starches into sugars. It gives substance to the suggestion with which I began, that there should be a con-

\footnotetext{
5 The fairly recent recognition of Bronze Age "burnt mounds" in Britain as cooking-places, comparable to the ethnohistorically-known fulachta fiadh from Ireland, indicates the way in which cooking at this period may have been organised (for certain purposes) at a non-domestic level; and who knows how different Neolithic practices may have been?

6 Such books are often hard to find, but can be encountered on the shelves of libraries dealing with these now unfashionable subjects, such as the Balfour Library of the Pitt Rivers Museum in Oxford, home of lost causes.

7 Published together with E. Cecil Curwen's Plough and Pasture: the early history of farming in a paperback edition of that title in 1961. I have slightly altered Hatt's staccato punctuation and paragraphing to aid the flow of the quotation. Words in square brackets are mine.

8 "Bannock": a round unleavened loaf traditional in northern Britain - Hatt had conducted ethnographic fieldwork in Scotland!
} 
trast between the diet of early farmers in Europe, and those of later prehistory and the historical period from which our principal direct evidence is derived. It suggests that the early farming inhabitants of Europe (and their predecessors in the Near East) may have had a radically different form of diet from their prehistoric successors, even where this was based on precisely the same species of crops. The two phases would have been separated by important innovations in food-processing, involving the use of fermentation techniques. This is the thesis that I would like to elaborate.

\section{REVISITING THE SECONDARY PRODUCTS REVO- LUTION}

My original intention in setting out the concept of an SPR in 1981 was to carry out the agenda of "radical defamiliarisation" set out above: to approach the Neolithic as something alien and distant, which could not be understood simply by projecting backwards the kinds of "traditional farming" familiar from preindustrial Europe and western Asia. It was a liberating experience to realise that practices such as milking of the use of animal fibres for textiles need not have been part of the farming package as it was introduced to Europe in the seventh millennium BC. The more specific idea that the later fourth millennium constituted an era of revolutionary change came principally from study of the traction complex - a combination of the evidence for ploughmarks, figurines of yoked oxen, and wheeled vehicles (the last being studied at the time by Stuart Piggott: 1983). This was also the principal reason for treating it as a phenomenon centred in the Near East, and impinging on Europe as an intrusive complex. It was also the time at which Colin Renfrew (1972) was noting the connection between the use of treecrops (vine and olive) in Early Bronze Age Greece and the appearance of ceramic assemblages with jugs, cups and other vessels for manipulating liquids. (Many of these were clearly skeuomorphic copies of metal originals, of which third-millennium examples are known.) His own interpretation was that this represented agricultural diversification and the (local) emergence of the "mediterranean triad" of cereals, vines and olives, which he saw as a precondition for the emergence of social complexity in the
Aegean through redistributive palatial economies which managed the exchange of these products. In the case of the Baden culture, however, where there was clear evidence of animal traction in the form both of cart models and paired-cattle burials, the contemporary appearance of jugs and cups could not be attributed to drinking wine, since vines were not cultivated in central Europe before the Iron Age/ classical period. Moreover the jugs and cups were prominent in precisely the same elite graves in Hungary as those which produced evidence for animal traction, so that both could be seen as part of an elite lifestyle introduced from outside. The same might also have been true of woollen textiles, and of domesticated horses.

This is not the place to consider the dating evidence for these features (which has accumulated considerably in the last 20 years, and I would claim still broadly supports my reconstruction: Sherratt 1997), but rather to inquire further into the significance of the ceramics. Seeking for some more basic liquid than Aegean wine as the substance served from elite drinking-vessels in central Europe, I plumped for milk and milk-products as an obvious possibility for a post-Neolithic innovation - not least because of the growing literature which indicated the relative rarity of lactose-tolerance in human populations, suggesting that milk-drinking was an unusual and possibly late practice. 9 This was a mistake, at least in part. Recent biochemical work on the identification of lipids from organic residues in prehistoric pottery (reported by Richard Evershed in this volume) has shown that milk has formed part of human diet since at least the beginning of the fourth millennium in the British Isles; and new interpretations of lactose tolerance have related it to the selective advantage of improved calcium absorption in areas where restricted sunlight reduces vitamin D production - especially among European populations, where fair hair- and skin-colour represents a parallel adaptation. Although milking is likely to represent a post-Neolithic innovation (and Richard Evershed has begun a systematic sampling programme of earlier Neolithic pottery from Europe and the Near East to identify the beginnings of its use), it was not in itself part of the SPR as defined by the introduction of the traction complex in the midfourth millennium.

\footnotetext{
9 The idea that milk, in societies in which it is rare or unknown, may have a special attractiveness is hard to grasp in societies such as ours which are saturated in dairy products; but the Viking settlers in Greenland noted that it was the single thing most desired by the native population, who of course were quite unfamiliar with it - and who would have had trouble in digesting it in large quantities, had it been available, because of their genetic intolerance to lactose. (Information from Klavs Randsborg, Copenhagen.)
} 
Instead, I turned to alcohol as the more obvious magic ingredient of the drinking-vessels in Cycladic EBA cemeteries, Baden-culture graves, and also the beakers prominent in Corded Ware and Bell-Beaker graves in northern and western Europe in the following millennium (Sherratt 1987). (This allowed a series of jokes about the antiquity of "drinking and driving", in reference to the Baden-culture wagonmodels, which are in fact wagon-shaped cups and perfectly exemplify the conjunction of these two elite elements.) While wine would have been the alcoholic beverage of the Aegean, other forms of fermented brews would have provided substitutes in temperate Europe. This was the beginning of a process of exploration, both of the history of alcohol and of other psychotropic substances, on which I reported in 1995 in an article entitled "Alcohol and its alternatives: symbol and substance in preindustrial cultures" (Sherratt 1995). Escaping from the essentialism of equating ceramic types with single substances, I discussed their role in conventionalised drinking rituals, practised in common over large areas and frequently singled out by archaeologists as the distinctive markers of cultural complexes. This interpretation chimed in with ideas then circulating about the social importance of the symposium in Homeric and classical Greek contexts, raised by Oswyn Murray (1990); and also with the work of Michael Dietler (1990) in a later period, who brought together ethnographic evidence for the importance of communal drinking and the spread of imported wine and drinking equipment amongst Celtic Iron Age groups in western Europe. Moreover the clear skeuomorphic echoes of metal vessels in Baden and Bronze Age Aegean pottery types provided an element of continuity with the practices of the classical world, as they were beginning to be discussed by my Oxford colleague Michael Vickers (Vickers and Gill 1994). It would be possible, therefore, to discuss this phenomenon simply in terms of modes of elite interaction and display, without any further implications for diet in general, and with the emphasis on new forms of human (especially male) sociality and interaction.

Nevertheless there are reasons for retaining a connection between subsistence and semiotics, or substance and style, and not rejecting the material basis of the original reconstruction. The association with tree-crops in the Aegean is real, and the association of these changes with a whole raft of innovations concerned with agriculture and livestock-raising lea- ves open the possibility that it did, indeed, coincide with profound alterations in the availability of certain types of food and the practices involved in their preparation. In particular, the emergence of an elite diet (and elite modes of clothing, or transport) implies a concentration of relatively rare substances such as fats and sugars (or animal fibres, or specialised forms of livestock) that are inherently expensive, and involved lengthened chains of preparation and investment in resources with alternative allocations and more immediate benefits. In the light of ethnographic descriptions (such as that from Gudmund Hatt quoted above) of the limited range of such expensive practices in the New World at the time of European contact, it seems not unlikely that expensive items of diet such as alcohol were introduced in elite contexts before they became more readily available to the rest of the population, rather than being promoted (and monopolised) from more general use. Indeed, one could go further and ask whether these practices would ever have arisen in the absence of some elite investment in such conspicuous modes of consumption.

All of these features - draught animals, woollen clothing, alcoholic drinks - were of course widespread in the Old World at the time of European expansion in the $16^{\text {th }}$ century, and well-documented as far back as historical records extend: but these were all (by definition) contexts already affected by urban modes of consumption. As David Clarke would have said, temperate (and most tropical) Neolithic farmers are extinct; but those which have survived down to recent times in places like New Guinea do not practice extended modes of food preparation (or for that matter possess specialised types of livestock, or spend much time making clothes). of course they have feasts, involving "admiration of fine and plentiful food, and the knowledge of its abundance" (Malinowski cited in Young 1971.159); but this takes the form of abundant pig-meat and piles of yams, not "cakes and ale".10 It is this former mode of feasting, which provides the best model for Neolithic Europe before the mid-fourth millennium, and before the special, costly foods and drinks, which became available after it. Of course there are (and were) many cultivators in non-urban societies (for instance in Africa) who brew beer and provide good ethnographic analogies for later prehistoric Europe, but they are societies whose culture has already been affected in fundamental ways by practices pioneered in more complex societies - not least, in the case of

10 A traditional English phrase for merrymaking, used as the title of a comic book by the novelist Somerset Maugham in 1930. 
Africa, by the spread of iron working. What I am suggesting is that our perceptions of earlier old World prehistory have been fundamentally skewed by our knowledge of recent history and ethnography, which concerns cultures that were already transformed by urban consumption-patterns, and which therefore provide misleading analogies for what life was like in Europe before 4000 BC: Die Vorzeit war ganz anders (as Lew Binford's book $\mathbf{1 1}$ was perceptively titled in its German edition). In particular, the early phases of farming in Europe were very different from those of the last five to six thousand years, and in some respects may have been more comparable with those of the foraging groups which preceded them than those of the later Neolithic and metal ages. It remains to show where the expensive innovations of the SPR - in terms of diet as well as technology - may have had their origins.

\section{THE IMPACT OF URBANISATION}

The common thread which links the animal-derived items of the secondary products revolution and the plant-derived items of Renfrew's mediterranean triad (wine and oil) or their temperate equivalents ("cakes and ale") are that these are all practices which require a degree of capital investment, in the sense that they imply a "deferred enjoyment" of the fruits of labour (and not necessarily by those who did the work!), which involves a longer time-frame and planning depth. The raising of specialised draught animals such as plough-oxen (which take four years before they are useful) or the growing of perennial fruit-trees (which also take many years before they yield fruit - four or five in the case of vines), are cases in point. It is a further extension of the contrast pointed out by Claude Meillassoux between the "immediate return" of the forager and the "delayed return" of the farmer: the long-delayed return of the specialised agriculturalist. Plough-based farming or the cultivation of tree-crops are thus distant precursors of the very extended production-chains characteristic of industrial food production, so that there is a long-term evolutionary process in which the phenomenon which I characterised as the secondary products revolution takes its place as a logical step between the two. Unlike Renfrew, however, I would argue that these things did not emerge independently in prehistoric Europe (whether the plants and animals needed to produce them were already present or not), because such practices could only occur in societies capable of concentrating the initial capital. Just as farming did not spontaneously appear everywhere, but only in the restricted areas of origin which we call the "nuclear regions", and just as the Industrial Revolution was a breakthrough which took place in western Europe and more specifically in Great Britain before spreading across the globe, so, I believe, production and consumption practices which involved long-delayed returns and consequently expensive items of equipment or food made their initial appearance in a particular area of origin and in special circumstances - namely, in the Fertile Crescent in the fourth millennium BC. Moreover this initial "consumer revolution" was part and parcel of the genesis of urbanism itself, which cannot be understood in isolation from the elaboration of consumption patterns and the birth of commodities.

The key to many of these issues is to be found in the origins of writing - or, more precisely, in the pictographic symbols used to record transactions in the later fourth millennium at Uruk and other centres of early urbanism. Thanks to a major project in Berlin (Nissen et al. 1990), these tablets can now be understood; and they typically record the delivery of quantities of grain, malt and milk to temple estates for the brewing of various kinds of beer or the production of "cheese" and butter-oil (ghee), or the delivery of bales of wool for weaving. The pictograms show the characteristic containers for the former, and bales of the latter. Moreover it is now clear that these impressed signs were preceded by tiny clay models in the shapes of these commodities, the so-called "complex tokens", intended to be kept in a clay envelope marked with a seal-impression (presumably as a record of goods received); and the pictographs had their origins in the reduction of this three-dimensional recording system into the two-dimensional form of a clay tablet. What is especially exciting for the archaeologist is that these signs are in effect pictures of the commodities they represent, and that these correspond with remarkable accuracy to the classes of ceramic containers such as spouted jars which are so prominent a feature of Uruk ceramic assemblages - and not least the earliest forms of wheelmade pottery, which are mass-produced containers. It is clear that this was an economy of scale, concerned with the mobilisation of quantities of raw materials for the production of manufactured foodstuffs and textiles. (It is also notable that the pictograms include signs for ploughs and wheeled sledges, which are

11 In its original English edition rather more blandly called In Pursuit of the Past (1983). 
amongst the earliest evidence for the traction complex.) The food (and drink) stuffs required large quantities of grain and milk probably produced on specialist temple estates using irrigation, ploughing and the kinds of intensive dairy herds shown on Uruk cylinder seals (e.g. Sherratt 1997.Fig. 6.12), supplying production-processes based on biotechnologies of fermentation using yeasts and lactic acid bacteria (Hesseltine 1979). It is precisely the artefacts associated with these forms of food-processing which provide the diagnostic markers of the "Uruk expansion", including the founding of colonies higher up the Euphrates, located to tap the raw materials of an extensive hinterland in eastern Anatolia, the Levant, and ultimately Egypt (Algaze 1993), thereby providing a mechanism for the dissemination of practices formerly confined to the alluvial area of the south Mesopotamian plain. It is thus particularly satisfying that one of the most puzzling but ubiquitous items associated with this diaspora, the crudely made "bevel-rim bowl", has recently been suggested to be a mould for the making of leavened bread ( $\mathrm{Mil}$ lard 1988). Hatt's prediction about the association between leavened bread and beer may have its archaeological correlate in this culturally diagnostic container.

None of these containers could be described as "prestige drinking-sets" in the manner of Aegeo-Anatolian EBA and Baden jugs and cups; but Mesopotamian representations show that beer was drunk through straws out of a large vessel, and individual serving-vessels and containers were not used.12 The origins of the "jug and cup complex" seem (as Renfrew originally perceived) to lie with wine-drinking: but the Aegean was on the edge of this area, or in a later extension of it, and its beginnings must be sought in the belt of mediterranean vegetation to the north of the Fertile Crescent, in eastern and central Anatolia and the adjacent parts of Iran. It is in this region that the earliest indications of viticulture have been found, and it seems likely that the formal conventions of wine-drinking emerged as a local response to the role of beer-drinking as it was introduced by Mesopotamian colonists. In both areas there was an intimate association between precious metal vessels and the precious alcoholic liquids drunk from them (Sherratt and Sherratt 2001), and the consumption of such expensive beverages was a mark of elite status (as, no doubt, was the consumption of leavened bread, the wearing of woollen textiles, and the possession of draught-oxen). These "knock-on ef- fects" of the Uruk expansion form a plausible historical context for the spread to southeast and central Europe of the classic innovations of the secondary products complex - itself part of the larger transformation of patterns of production and consumption associated with early urbanisation. The association of drinking and driving was not fortuitous.

I have tried to show that the wave of changes in pottery types, which passed across Europe in the fourth and third millennia, altering as it went (as the cycle of outside stimulus and local response was repeated many times), can indeed be plausibly associated with innovations in diet. But what was the nature of these changes? What was drunk from Baden cups or Corded Ware beakers? The easy answer is "alcohol", but alcohol before the Industrial Revolution was never pure, and always part of a complex mixture (Sherratt 1987; 1995; cf. Völger and von Welck 1981), so it would be more accurate to say "local brews" (probably incorporating local psychotropic plant products already in use for smoking). Even this, however, is to oversimplify the picture, because it is the variety of new food practices, and the interactions between them, which is revealed by the Mesopotamian evidence. On the one hand there were dates (and their associated yeasts), important as a source of sugar added to cereal grains in both brewing and baking (bappir-bread), but which were restricted to the lowlands and whose role was to some extent transferred to other mediterranean fruits such as grapes (and in northern Europe to hedge-fruits and honey). Then there were milk products (such as ghee, possibly used for cooking but also drunk as a beverage, flavoured with herbs); and lactic acid bacteria which both add flavour to beer and bread and also produce the acidic conditions which assist in fermenting the sugars to alcohol, as well as inhibiting the action of less desirable microorganisms, enhancing keeping properties. It was often the combination of elements, in strange (and, to us, probably repulsive) mixtures for which we have no equivalent words in modern languages, which must have characterised the kind of cuisine I am attempting to describe. In the ultimate analysis it was not the individual technologies of food-preparation themselves which were distinctive as the fact that they involved a concentration of relatively expensive elements and implied lengthened production-chains and additional labour costs, so that they were not necessarily equally available to society as a whole: indeed, the whole process of using fermentation technologies is

12 Queen Pu-Abi was buried with a gold bowl and drinking-tube in the Royal Cemetery at Ur in the mid-third millennium. 
one which has been described as "biological ennoblement" (Platt 1964),13 and this metaphor itself conveys a degree of exclusiveness and added value.

Along with new foods would have been a change in the nature of feasting, from simply the provision of abundant food to the concentration of resources in order to prepare more complex items (and especially, but not exclusively, intoxicating beverages), ${ }^{\mathbf{1 4}}$ implying control of wider social networks to procure supplies of relatively rare or expensive resources. In this respect the provision of food parallels other items of material culture such as metalwork or clothing, which might also be described in similar terms. Social and material complexity form two aspects of a co-evolutionary process, in which social differentiation permits new forms of material manipulation, while new forms of consumption potentiate new types of social structures to control and monopolise them.

In the end, therefore, there is no simple label to substitute for my cumbersome phrase of the "secondary products revolution". In historical terms, it was one more episode in which the unusual conditions of western Asia and the east Mediterranean provided a conjunction of circumstances for a rapid burst of innovations, whose fallout affected neighbouring regions such as temperate Europe. In that respect, it is strikingly similar to the beginning of farming itself. If the picture which I have sketched is correct, however, and these innovations were essentially generated in the economies of scale which characterised the first cities (on the basis both of their distinctive local crops and their peculiar social institutions), then it was nothing other than Gordon Childe's Urban Revolution itself which was responsible for this second round of transformation in early European diets, cuisine, and ways of life. Selected, re-contextualised, and reinterpreted, the innovations to which it gave rise permeated the fabric of existing communities and permanently altered the character of prehistoric Europe.

ACKNOWLEDGEMENTS
I must thank Miha Budja for his invitation to speak
at the meeting, and his diplomatic skill in extracting
a written version from me. Božidar and Svetlana
Slapšak provided memorable hospitality in Ljubljana.

13 I owe this reference to Delwen Samuel - who nevertheless remains sceptical about my use of this argument.

14 The increasing (if initially limited) supply of alcoholic beverages would also have altered the role of other plant-products, previously used in a more exclusive or "shamanic" way to induce trance states of mind among privileged sections of the population. Indeed, we might expect a long-term trend - from individual trance states to collective inebriation - in which the use of alcoholic beverages took over the social role of quite distinct sets of substances with "magical" mind-altering properties: a process which I have called the "domestication of ecstasy". 


\section{REFERENCES}

ALGAZE G. 1993. The Uruk World System: the dynamics of expansion of early Mesopotamian civilization. Chicago: Chicago University Press.

BINFORD L. R. 1983. In Pursuit of the Past: decoding the archaeological record. London: Thames and Hudson.

DIETLER M. 1990. Driven by drink: the role of drinking in the political economy and the case of Early Iron Age France. Journal of Anthropological Archaeology 9(4): 352-406.

HATT G. 1961. Farming of non-European peoples. In E. C. Curwen and G. Hatt (eds.), Plough and Pasture: the early history of farming.

HESSELTINE C. W. 1979. Some fermented foods of Mid-Asia, the Middle East, and Africa. Journal of the American Oil Chemists Society 56: 367-74.

MAURIZIO A. 1927. Die Geschichte unserer Pflanzennahrung: von den Urzeiten bis zur Gegenwart. Berlin: Parey. French translation (1932), Histoire de l'alimentation végétale depuis la préhistorique (sic) jusqu'a nos jours. Paris: Payot.

1933. Geschichte der gegorenen Getränke. Berlin: Parey. Also reprinted (1970), Wiesbaden: Sändig.

MILLARD A. 1988. The bevelled-rim bowls: their purpose and significance. Iraq 50: 49-57.

MURRAY 0. (ed.) 1990. Sympotica: a symposium on the Symposion.

NISSEN H.-J., DAMEROW P. and ENGLUND R. K. 1990. Frühe Schrift und Techniken der Wirtschaftsverwaltung im Alten Orient: Informationsspeicherung und -verarbeitung vor 5000 Jahren. Berlin: Franzbecker.

PIGGOTT S. 1983. The First Wheeled Transport: from Atlantic Coast to the Caspian Sea. London: Thames and Hudson.

PLATT B. S. 1964. Biological ennoblement: improvement of the nutritive value of foods and dietary regimens by biological agencies. Food Technology 18 (5): $68-76$.
RENFREW C. 1972. The Emergence of Civilisation: the Cyclades and the Aegean in the third millennium BC. London: Methuen.

SHERRATT A. 1981. Plough and pastoralism: aspects of the Secondary Products Revolution. In I. Hodder, G. Isaac and N. Hammond (eds.), Pattern of the Past: studies in honour of David Clarke: 261-305. Revised and reprinted in Sherratt (1997).

1987. Cups that cheered. In W. Waldren and R. C. Kennard (eds.), Bell Beakers of the Western Mediterranean (BAR Int. Ser. 287), Oxford: British Archaeological Reports: 81-114. Revised and reprinted in Sherratt (1997).

1995. Alcohol and its alternatives: symbol and substance in pre-industrial cultures. In J. Goodman, P. Lovejoy and A. Sherratt (eds.), Consuming Habits: drugs in history and anthropology: 11-46.

1995. Economy and Society in Prehistoric Europe: changing perspectives. Edinburgh: Edinburgh University Press.

1999. Cash-crops before cash: organic consumables and trade. In C. Gosden and J. Hather (eds.), The Prehistory of Food: appetites for change: 13-34.

SHERRATT A and SHERRATT S. 2001. Technological change in the East Mediterranean Bronze Age: capital, resources and marketing. In A. Shortland (ed.), The Social Context of Technological Change: Egypt and the Near East 1650-1150 BC: 15-38.

VICKERS M. and GILL D. 1994. Artful Crafts: ancient Greek silverware and pottery. Oxford: Clarendon Press.

VÖLGER G. and von WELCK K. (eds.) 1981. Rausch und Realität.

YOUNG M. W. 1971. Fighting with Food: leadership, values and social control in a Massim society. Cambridge: Cambridge University Press. 